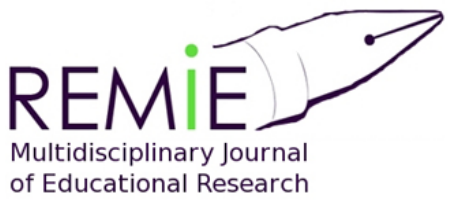

Hipatia Press

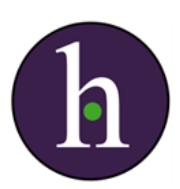

Instructions for authors, subscriptions and further details:

http://remie.hipatiapress.com

\title{
Development of an Academic Achievement Risk Assessment Scale for Undergraduates: Low, Medium and High Achievers
}

Tahira Jibeen ${ }^{1}$, Masha Asad Khan²

1) COMSATS Institute of Information Technology, Lahore, Pakistan

2) Forman Christian College: A Charted University, Lahore, Pakistan

Date of publication: February $15^{\text {th }}, 2016$

Edition period: February 2016-June 2016

To cite this article: Jibeen, T., \& Khan, M. A. (2016). Development of an Academic Achievement Risk Assessment Scale for Undergraduates: Low, Medium and High Achievers. Multidisciplinary Journal of Educational Research, 6(1), 23-50. doi:10.17583/remie.2016.1697

To link this article: http://dx.doi.org/10.17583/remie.2016.1697

\section{PLEASE SCROLL DOWN FOR ARTICLE}

The terms and conditions of use are related to the Open Journal System and to Creative Commons Attribution License (CC-BY). 


\section{Development of an Academic Achievement Risk Assessment Scale for Undergraduates: Low, Medium and High Achievers}

Tahira Jibeen

COMSATS Institute of

Information Technology,

Lahore, Pakistan
Masha Asad Khan

Forman Christian College:A

Charted University,

Lahore, Pakistan

\section{Abstract}

This research has developed The Academic Achievement Risk Assessment Scale [AARS], for identification of the factors which influence performance of undergraduate (448 students); studying at three universities of Lahore, Pakistan. An 18-item scale, with five distinct factors was developed which included lack of motivation, dysfunctional parental practices, parental involvement in drug abuse or antisocial activities, difficulty with peers, and language barrier. The results revealed differences among low, medium and high academic CGPA groups as all five risk factors were significantly related to the low achieving group. The study has implications for teachers, counselors, and policy makers in the field of learning.

Keywords: lack of motivation, dysfunctional parental practices, parental involvement in antisocial activities, high academic achievers, low academic achievers 


\section{Desarrollo de una Escala de} Evaluación de Riesgos en el Logro Académico para Estudiantes Universitarios: Alumnado con Altas, Medias y Bajas Calificaciones

Tahira Jibeen

COMSATS Institute of

Information Technology.

Lahore, Pakistan
Masha Asad Khan

Forman Christian College:A

Charted University,

Lahore, Pakistan

\section{Resumen}

Esta investigación ha desarrollado la Escala de Evaluación de Riesgos en el Logro Académico [AARS], para la identificación de los factores que influyen en el rendimiento de los estudiantes de grado (448 estudiantes); estudiados en tres universidades de Lahore, Pakistán. Se desarrolló una escala de 18 ítems, con cinco factores distintos, incluyendo la falta de motivación, prácticas parentales disfuncionales, participación de los padres en el abuso de drogas o actividades antisociales, dificultades con el grupo de pares, y barrera idiomática. Los resultados revelaron diferencias entre los grupos bajos, medios y altos en la CGPA, puesto que los cinco factores de riesgo se relacionaron significativamente con el grupo de bajo rendimiento. El estudio tiene implicaciones para profesorado, profesiones de la orientación y responsables de las políticas en el ámbito del aprendizaje.

Palabras clave: falta de motivación, prácticas parentales disfuncionales, participación de los padres en actividades antisociales, dificultades con el grupo de pares, barrera idiomática, rendimiento académico bajo 
- tudents' academic performance plays a vital role in producing the best quality graduates who are responsible for a country's economic and social development. The performance of students in universities is a concern not only to the administrators and educators, but also to corporations in the labour market (Ali, Jusoff, Ali, Mokhtar, \& Salamat, 2009). The employers pay great attention to academic achievement level of workers and recent graduates while recruiting. It is important to note that the problem of low academic achievement is one of the great crises of the educational system in third world countries. The problem of low academic achievement has been identified several times as problematic in terms of social and economic waste (Peelo \& Wareham, 2002).

Previous statistics indicated that $40 \%$ college students leave higher education without getting a degree and $75 \%$ of students leave within their first two years of college (Deberard, Spielmans, \& Julka, 2004). Education for All (EFA) Global Monitoring Report (UNESCO, 2005) suggested that only $41.5 \%$ of people older than 15 years of age are literate in Pakistan having the highest dropout rates in South Asian countries, with just over 10 percent of students finishing twelve years of schooling (Akram \& Khan, 2007). The recent Barro-Lee's (2010) data indicated that percentage of students who complete college education range $4 \%$ to $6 \%$ in Pakistan indicating very low rate in comparison with developed countries (Barro \& Lee, 2010).

In Pakistan, the academic achievement is calculated by the CGPA (Cumulative Grade Point Average) that shows the overall academic performance of a student where it considers the average of all examination grades for all semesters during the tenure in a university (Ali et al., 2009). The students performing on the on the low end of the continuum are considered low achievers, with a grade point average below a B (below 70th percentile) on a five-point grading system (e.g., A, B, C, D, and F) while high achievers perform on the high end of the continuum with a grade point average above a B (above 80th percentiles) on a five-point grading system (Cohen, 2001).

Researchers try to relate the constructs of individualist and collectivist culture with specific psychological functioning of the individual (e.g., 


\section{Jibeen \& Khan - Risk Factors Academic Achievement}

behavior, attitudes, cognitions, norms, values, goals). In general, group cohesiveness, emotional interdependence, obligation, and group solidarity are characteristics of collectivistic societies whereas personal autonomy, emotional independence, singular actions, and personal goals are related to individualistic societies (Pearson \& Child, 2007; Triandis, 1989). As Pakistan is a collectivist culture, the social pattern is characterized by differences in things such as family living arrangements (e.g., collectivism tends to larger families and extended families living under the same roof), social behavior (e.g., collectivists tend to show greater conformity to group norms), beliefs, political ideologies and so on. Because of these trends educational researchers are interested in studying the academic success and adjustment of college students of different societies (Dennis, Phinney, \& Chuateco, 2005, p. 223).

Risk factors related to academic achievement are those conditions that increase the likelihood of a student' being of the school dropout or low academic achievers. Of all the personal and psychological factors that have attracted researchers in the area of educational achievement, motivation seems to be gaining more popularity and leading other variables (Awan, Noureen, \& Naz, 2011). Motivation is defined as a set of interrelated beliefs and emotions that influence and direct behaviors (Martin, 2009). It has been indicated that low achievers show various motivational problems including a lack of participation in the class, lower self motivation, less goal directed behavior and more negative or non-cooperative attitudes toward institution, teachers or studies than high achievers (Downey \& Yuan, 2005; Ma \& Xu, 2004; McCoach \& Siegle, 2001; 2003a; Tella, 2007).

Literature documents that positive parental support and nurturance promotes higher academic attainment whereas dysfunctional parental practices have been defined as a potential risk factor for poor academic performance among early and late adolescents (Aunola, Stattin, \& Nurmi, 2000; Dennis et al, 2005; Hickman, Kim, \& Rohner, 2002; Kordi \& Baharudin, 2010). These practices comprise poor parent-child communication, permissive or strict parenting, less acceptance, less supervision, and more conflict towards their children (Moss \& St.-Laurent, 2001; Shek, Lee, \& Chan, 1998; Stewart, 2007). Further, studies have reported positive relations between peer acceptance or peer support and 
academic success among both children and adolescents (Fass \&Tubman, 2002). It has been found that perceived same-sex and opposite sex peer relationships yield positive direct and indirect links with academic performance and general self-esteem (Liem \& Matin, 2011). Moreover, low peer acceptance or peer rejection in adolescence has been identified as a risk indicator for poor school adjustment including academic failure (Buhs \& Ladd, 2001).

Moreover, parental substance or alcohol abuse also increases a child's risk for behavioral problems that include drug and alcohol abuse, socialskill deficits, and low educational attainment (Fillmore, 1987; Solis, Shadur, Burns, \& Hussong, 2012; Winters, 2006). Findings indicate that children from anti-social alcoholic families are most susceptible to relative intellectual, cognitive, and academic deficits. Another individual factor related to low academic performance is language barrier. A number of studies have examined the correlation between language proficiency and academic performance among post-secondary students (Butler \& CastellonWellington, 2005; Francis \& Rivera, 2007; Parker, Louie, \& O’Dwyer, 2009). It has been suggested that limited-English-proficient students achieve lower academic grades as well as drop out of school (Rumberger \& Larson, 1998).

The main objective of this study was to develop a multidimensional measure of academic achievement risk (personal, familial and peers' related) factors for low academic achievement among Pakistani undergraduate students. Further, to check the validity of the newly developed scale in differentiating low, medium and high academic achievers on identified risk factors in different domains. Therefore, it was hypothesized that low academic achievers are significantly different from high and medium achievers regarding the level of academic achievement motivation, dysfunctional parental practices, parental involvement in drug abuse or antisocial activities, and relationship problems with peers and language-barrier. 


\section{Method}

\section{Participans and Procedure}

The final sample for the present study was comprised of 448 undergraduate students studying at three universities including COMSATS Institute of Information Technology, University of Management Sciences and University of Central Punjab, Lahore, Pakistan (Table 1). Initially, 20 participants were contacted for item generation. The sample included 10 male and 10 female undergraduate students with low CGPA (below 2.51). Afterwards, the clarity and comprehensiveness of the initially formed items was assessed using a separate sample of 30 (22 male and 8 female) undergraduate students. Finally, the exploratory factor analysis was conducted with 448 undergraduate students studying at three universities mentioned above (Table 1).

A range of demographic information including age, gender, CGPA, semester, mother education, father education, system of living arrangement, parental status, and level of income satisfaction (from 1-not at all satisfied to 4-highly satisfied) was inquired from participants. These questions were based on a review of the relevant research literature (Bean, Bush, McKenry \& Wilson, 2003; Buddy, 2007; Buhs \& Ladd, 2001; Diaz, 2003; Eamon, 2005; Oliverez \& Tierney, 2005; Turner, Chandler \& Heffer, 2009).

The average age of students was 20.32 years $(\mathrm{SD}=1.83)$ and it was composed of primarily males (88\%) as compared to females (12\%). In terms of income comfort level, on a scale from 1 (not at all satisfied) to 4 (high level of comfort), the mean was $2.1(\mathrm{SD}=1.0)$. The mean number of family members in home was 6.5 ( $\mathrm{SD}=3.27)$. Seventy three percent of the participants belonged to nuclear and $26 \%$ came from joint family living arrangement. In terms of medium of instruction, $38 \%$ of the participants had Urdu, while $60 \%$ of the participants had English background. For the purpose of this study, three groups were created based on their self-reported CGPAs on a five-point grading system: low (CGPA at or below 2.50 or 
below 70th percentile), medium (CGPA ranged 2.51 to 3.0 or 70th to 79th percentile) and high (CGPA above 3.1or above 80th percentiles) (Table 1).

Table 1

Study Sample Characteristics $(N=448)$

\begin{tabular}{|c|c|c|c|c|}
\hline Variables & $M$ & $S D$ & Frequency & Valid \% \\
\hline CGPA & 2.68 & .57 & & \\
\hline Low & & & 159 & $35.6 \%$ \\
\hline Middle & & & 144 & $32.2 \%$ \\
\hline High & & & 144 & $32.2 \%$ \\
\hline Semester & & & 185 & 41.6 \\
\hline Second & & & 99 & 22.2 \\
\hline Third & & & 54 & 12.1 \\
\hline Forth & & & 32 & 7.2 \\
\hline Fifth & & & 23 & 5.2 \\
\hline Sixth & & & 25 & 5.1 \\
\hline Seventh & & & 26 & 5.8 \\
\hline Eighth & & & 26 & 5.8 \\
\hline \multicolumn{5}{|l|}{ Income satisfaction level } \\
\hline Highly satisfied & & & 186 & 42.43 \\
\hline To some extent satisfied & & & 153 & 34.8 \\
\hline $\begin{array}{l}\text { To some extent not } \\
\text { satisfied }\end{array}$ & & & 58 & 13.2 \\
\hline Not at all satisfied & & & 42 & 9.5 \\
\hline \multicolumn{5}{|l|}{ Father education } \\
\hline Less than metric & & & 25 & 5.9 \\
\hline Metric & & & 49 & 11.6 \\
\hline Intermediate & & & 56 & 13.3 \\
\hline Graduate & & & 139 & 33.0 \\
\hline Master & & & 82 & 19.5 \\
\hline Professional & & & 64 & 15.2 \\
\hline $\mathrm{PhD}$ & & & 6 & 1.4 \\
\hline
\end{tabular}


30 Jibeen \& Khan-Risk Factors Academic Achievement

Table 1 (cont.'d)

Study Sample Characteristics $(N=448)$

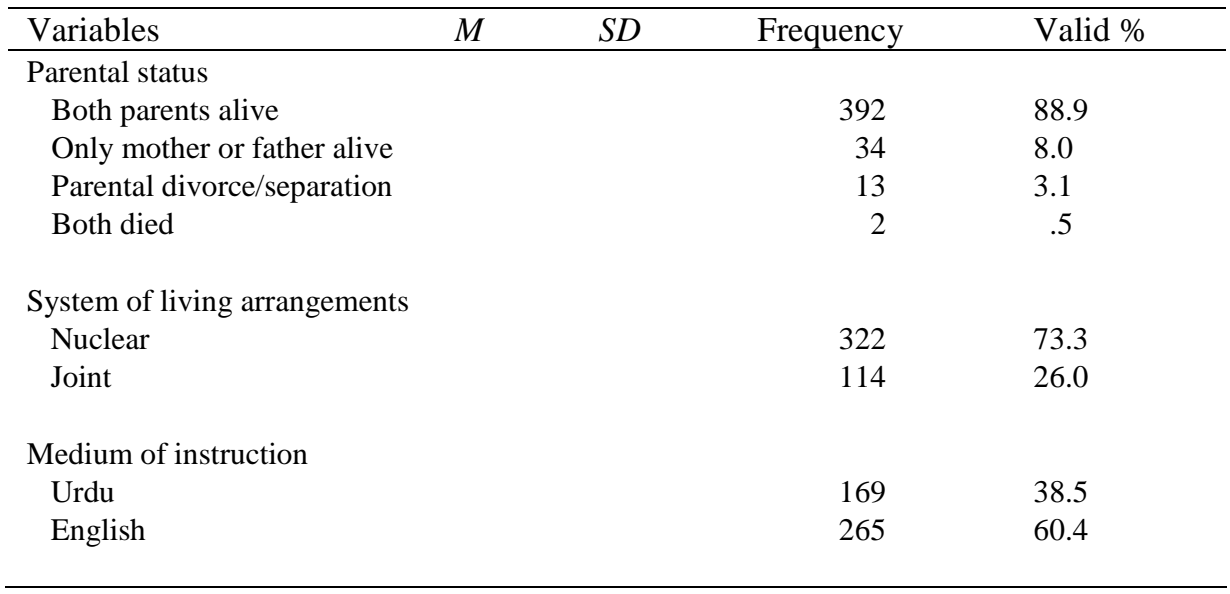

Note. The numbers do not always lead up to 448 as a result of some missing data

\section{Stages of Scale Development}

The Academic Achievement Risk Assessment Scale was developed following the sequential stages given below.

Item generation and content validity. The first step was generation of the items and content validity was the main aim of this step which was accomplished by a theoretical framework and employing a careful sorting process. Through this process, items were matched to construct definition. The literature indicated that different factors affect college students' academic performance (Buddy, 2007; Buhs \& Ladd, 2001; Casanova et al., 2005; Kirby \& Sharpe, 2001; McCoach \& Siegle, 2003b; Rumberger \& Larson, 1998). This scale was developed based on combined inductive and deductive approach and therefore, items were derived from two sources: (a) a review of the literature, including studies on low academic achievement 
factors; and (b) unstructured interviews with undergraduate students with low CGPA. In the current study, the researchers did not establish specific hypothesis regarding the core factor structure of the scale items. Through this process, the researchers came up with 45 items that were then assessed by five subject matter experts including the researcher themselves.

Inter-item correlations and expert feedback. In the second step, the initially generated 45 items were presented to five subject matter experts including the researcher themselves. They assessed the items and provided feedback regarding face and construct validity, comprehensibility and comprehensiveness.

The experts analyzed the items to evaluate its content validity and provided an explanation of the meaning of each item and outlined the objectives, concepts, and definitions of the items. The three steps that were taken were checking for agreement among the experts, discussion, and consensus. The experts ranked each item's priority, deleted or added comments, and provided a level of agreement for each item. Only those items were retained for further analysis when these experts provided $80 \%$ agreement or consensus (Lynn, 1986). As a result of expert feedback, 10 items were excluded and consequently, 35 items remained for the next procedure.

Item categorization and pilot study. In this step, the researchers sorted 35 items into different categories (Churchill, 1979) and applied these items on thirty participants. Different categories included lack of motivation (7items), dysfunctional parental practices (7-items), parental involvement in drugs or antisocial activities (4-items), relationship problems with peers (5items), and language barrier (4-items), and miscellaneous problems (8items). This categorization of items was based on the consensus among three coders (two doctoral students and one researcher herself). The coders independently back translated the 35 -items into the different categories to further refine the assignment of the items into categories mentioned above. The only criterion for retaining the item for further analysis was agreement between coders. As a result of participants' feedback, the five point rating scale $(1=$ not at all, $2=$ very less, $3=$ less, $4=$ mostly, $5=$ always $)$ was 


\section{Jibeen \& Khan - Risk Factors Academic Achievement}

changed to four point scale and the options for the responses were changed into " Disagree $=1$ ', "To some extent disagree $=2$ "', "To some extent agree $=3$ ', and 'Agree $=4$ ', Lower scores indicate a lower level of risk factors and higher scores show higher level of risk factors. The purpose of this change was to adjust the opinions of the responses according to the wordings of these items and to get more meaningful responses.

After getting the coders' ratings and pilot study, the researchers eliminated 5 repeated and poorly functioning items leaving a pool of 30items for further analysis. The 30-items were divided into different categories for further analysis including lack of motivation (6-items), dysfunctional parental practices (6-items), parental involvement in drugs or antisocial activities (3-items), relationship problems with peers (4-items), and language barrier (3-items), and miscellaneous problems (8-items).

The following stages are related to the validation and refinement of the 30 items on the final sample of 448 participants.

\section{Results}

\section{Exploratory Factor Analysis (EFA)}

Principal Component Analysis technique was applied on the correlation matrix of the final 30 items. Bartlett's test of sphericity (Bartlett, 1954) was significant $\left(\mathrm{p}_{-} .0001\right)$, showing that the data were adequately distributed to allow an evaluation of the potential factor structure. Next, Kaiser-MeyerOlkin yielded a value of .82, indicating that the ratio of the number of participants to AARS items was sufficient to run a principal-component factor analysis. The factors were based on the following criteria including : (a) an unrotated eigen value $>1$ with a category factor loadings of at least .35 (b) a simple structure with each factor different from one another and with all items loading highly on one factor (c) and interpretability, that the factor represents a meaningful underlying aspect (Zeller \& Carmines, 1980).

The Kaiser criterion and the total explained variance criteria were also used for the determination of "meaningful" factors (Kaiser, 1974). The five factor solution most closely corresponded to the best approximation of 
simple structure with the fewest number of cross-loadings and it yielded the most interpretable solution.

The principal component analysis, item loadings and communality coefficients for the final 18 items are presented in Table 2.

\section{Table 2}

Mean, Standard Deviation, EFA Factor Loadings and Communalities of 18-item Risk Assessment Scale $(N=448)$

\begin{tabular}{|c|c|c|c|c|c|c|c|c|c|}
\hline Items & Item description & $\mathrm{M}$ & SD & 1 & 2 & 3 & 4 & 5 & $h^{2}$ \\
\hline 1 & $\begin{array}{l}\text { I feel lack of participation in } \\
\text { class. }\end{array}$ & 1.38 & 1.08 & .81 & & & & & .70 \\
\hline 2 & $\begin{array}{l}\text { I am dissatisfied with my } \\
\text { teachers. }\end{array}$ & 1.26 & 1.07 & .77 & & & & & .62 \\
\hline 3 & $\begin{array}{l}\text { I feel inattentive or unmotivated } \\
\text { towards my studies. }\end{array}$ & 1.43 & .99 & .73 & & & & & .68 \\
\hline 4 & $\begin{array}{l}\text { I feel inattentive or unmotivated } \\
\text { towards my teachers. }\end{array}$ & 1.07 & .98 & .71 & & & & & .65 \\
\hline 5 & $\begin{array}{l}\text { I think that my education is not } \\
\text { according to my personal desires. }\end{array}$ & 1.00 & 1.19 & .75 & & & & & .58 \\
\hline 6 & $\begin{array}{l}\text { My parents have strict attitude } \\
\text { with me. }\end{array}$ & .65 & 1.01 & & .65 & & & & .55 \\
\hline 7 & $\begin{array}{l}\text { My parents have low expectations } \\
\text { regarding my academic success. }\end{array}$ & .66 & .99 & & .79 & & & & .67 \\
\hline 8 & $\begin{array}{l}\text { There is poor communication } \\
\text { between my university and home. }\end{array}$ & 1.23 & 1.53 & & .75 & & & & .64 \\
\hline 9 & $\begin{array}{l}\text { My parents do not emphasis on } \\
\text { importance of education. }\end{array}$ & .55 & 1.99 & & .68 & & & & .62 \\
\hline 10 & $\begin{array}{l}\text { I have family disturbances (e.g., } \\
\text { violence situation in home). }\end{array}$ & .36 & .82 & & .65 & & & & .61 \\
\hline 11 & $\begin{array}{l}\text { One or both of my parents are } \\
\text { indulged in alcohol or drug } \\
\text { problems. }\end{array}$ & .20 & .62 & & .52 & & & & .47 \\
\hline 12 & $\begin{array}{l}\text { One or both of my parents have } \\
\text { criminal or jail history. }\end{array}$ & .22 & .69 & & .51 & & & & .49 \\
\hline
\end{tabular}


Table 2 (cont.'d)

Mean, Standard Deviation, EFA Factor Loadings and Communalities of 18-item Risk Assessment Scale $(N=448)$

\begin{tabular}{|c|c|c|c|c|c|c|c|c|c|}
\hline Items & Item description & M & SD & 1 & 2 & 3 & 4 & 5 & $h^{2}$ \\
\hline 13 & $\begin{array}{l}\text { I have difficulty in relating to my } \\
\text { peer group (participating in group } \\
\text { activities like gathering, playing } \\
\text { etc). }\end{array}$ & .68 & 1.04 & & & & .73 & & .73 \\
\hline 14 & $\begin{array}{l}\text { I have negative attitude with my } \\
\text { peer group. }\end{array}$ & .67 & 2.03 & & & & .66 & & .76 \\
\hline 15 & $\begin{array}{l}\text { I feel uncomfortable in co- } \\
\text { education environment. }\end{array}$ & .86 & 1.01 & & & & .68 & & .81 \\
\hline 16 & $\begin{array}{l}\text { I have relationship problem with } \\
\text { opposite gender. }\end{array}$ & .87 & 1.02 & & & & .61 & & .70 \\
\hline 17 & $\begin{array}{l}\text { I feel difficulty to communicate in } \\
\text { English. }\end{array}$ & 1.04 & 1.07 & & & & & .69 & .78 \\
\hline 18 & $\begin{array}{l}\text { I feel difficulty to write or express } \\
\text { in English. }\end{array}$ & 1.12 & 1.04 & & & & & .65 & .79 \\
\hline
\end{tabular}

Note. Item 1 to 5 = Lack of motivation; Item 6 to $10=$ Dysfunctional parental practices; Item 11 to $12=$ Parental involvement in drugs or antisocial activities; item 13 to $16=$ Relationship problems with peers; Item 17 to $18=$ Language Barrier.

The final components were consisted of those selected items with a factor loading at least 0.50 on a specific component, cross-loadings not exceeding 0.30 , and loading on two factors with the difference of less than 15 units. The items with miscellaneous problems (8-items) components did not meet the minimum retaining criteria of 0.50 values and items with cross-loadings with the difference of less than 15 units were deleted.

After item deletion, 18-items with five factors were retained including Lack of motivation, Dysfunctional parental practices, Parental involvement in drugs or antisocial activities, Relationship problems with peers and Language Barrier (see Table 2). The five factors accounted for $25.81 \%$, $10.10 \%, 7.89 \%, 6.84 \%$, and $6.13 \%$ variance respectively. The overall 
variance accounted for $57 \%$, while the communalities ranged from .36 to .80 after extraction (see Table 2 ). The four point Likert-type scales ranging from 1 (completely disagree) to 4 (strongly agree) were used for 18 -items (see Appendix A). The resulting total 18-items AARAS had a coefficient alpha of .81 and the lack of motivation, dysfunctional parental practices, parental involvement in drugs or antisocial activities, relationship problems with peers and language-barrier subscales had alphas of $.80, .81, .82, .79$, and .64 , respectively ranging from moderate to high. Although these results were promising, data-driven modifications to instruments may capitalize on chance (Jöreskog, 1993). Thus, further investigation into the reliability of the AARAS with an independent sample is needed. The 18-items were administered to a separate 40 participants (67\% male and $32 \%$ female) in second reliability analysis study. The five subscale and total inter correlations were moderate to large in size, ranging from $r=.64$ to $r=.82$.

The results from ANOVA did not indicate any significant gender effect for the lack of motivation $(\mathrm{F}=.314, \mathrm{p}=.57)$, dysfunctional parental practices $(\mathrm{F}=1.42, \mathrm{p}=.23)$, parental involvement in drugs or antisocial activities $(\mathrm{F}=.29, \mathrm{p}=.53)$, relationship problems with peers $(\mathrm{F}=.11, \mathrm{p}=$ $.73)$, and language barrier $(\mathrm{F}=3.30, \mathrm{p}=.07)$. Five parametric analyses of variance procedures were performed to examine the difference between three academic achievement groups based on CGPA. Bonferroni method of adjustment was utilized such that each statistical analysis had to reach a level of .01 for a result to be considered statistically significant. A one way ANOVA showed that the three groups (low, medium and high CGPAs) were statistically significant regarding lack of motivation, $\mathrm{F}(2, \mathrm{~N}=402)=$ $15.44, \mathrm{p}<.0001$, dysfunctional parental practices, $\mathrm{F}(2, \mathrm{~N}=427)=8.50$, $\mathrm{p}<.001$, parental involvement in drugs or antisocial activities, $\mathrm{F}(2, \mathrm{~N}=$ $439)=7.07, \mathrm{p}<.01$, relationship problems with peers, $\mathrm{F}(2, \mathrm{~N}=414)=$ $7.7, \mathrm{p}<.0001$, and language barrier, $\mathrm{F}(2, \mathrm{~N}=437)=6.65, \mathrm{p}<.01$ (Table 3). 
36 Jibeen \& Khan - Risk Factors Academic Achievement

Table 3

Analysis of Variance for Differences in Scores by Academic Achievement Groups ( $N$ $=448$ )

\begin{tabular}{llllll}
\hline Variables & Source & $\begin{array}{l}\text { Sum of } \\
\text { Squares }\end{array}$ & $d f$ & MS & $F$ \\
& & 317.31 & 2 & 158.65 & $15.44 * * *$ \\
Lack of motivation & Between & 4107.76 & 400 & 10.26 & \\
& Within & 4425.07 & 402 & & \\
& Total & 165.13 & 2 & 82.56 & $8.50^{* *}$ \\
Dysfunctional parental & Between & 4125.03 & 425 & 9.70 & \\
practices & Within & 4290.16 & 427 & & \\
& Total & & & & \\
Parental involvement & Between & 23.38 & 2 & 11.69 & $7.07 * *$ \\
in drugs or antisocial & Within & 721.88 & 437 & 1.65 & \\
activities & Total & 745.26 & 439 & & \\
Relationship problems & Between & 128.26 & 2 & 64.13 & $7.77 * * *$ \\
with peers & Within & 3397.86 & 412 & 8.24 & \\
Language-barrier & Total & 3526.13 & 414 & & \\
& Between & 33.39 & 2 & 16.70 & $6.65 * *$ \\
& Within & 1091.77 & 435 & 2.51 & \\
\hline
\end{tabular}

Note. The numbers do not always lead up to 448 due to some missing data. $* \mathrm{p}<.05$, ** $\mathrm{p}<$ $.01, * * * \mathrm{p}<.001$.

Because the overall test was significant, post-hoc tests (i.e., Tukey's HSD) were used to decompose and interpret the results of the ANOVA. The post-hoc comparisons revealed that the mean scores of low CGPA group was typically higher than high CGPA regarding all risk factors including lack of motivation, $\mathrm{M}=2.154, \mathrm{SD}=.3888, \mathrm{p}<.0001$, dysfunctional parental practices, $\mathrm{M}=1.517, \mathrm{SD}=.3679, \mathrm{p}<.001$, parental involvement in drugs or antisocial activities, $\mathrm{M}=8.5549, \mathrm{SD}=.1495, \mathrm{p}<$ .01 , relationship problems with peers, $\mathrm{M}=1.328, \mathrm{SD}=\mathrm{p}<.0001$, and language barrier, $\mathrm{M}=.6422, \mathrm{SD}=.1847, \mathrm{p}<.01$. Further, the high CGPA group was significantly different from medium CGPA group regarding lack of motivation, $\mathrm{M}=-1.27481, \mathrm{SD}=.39596, \mathrm{p}<.01$, and relationship problems with peers, $\mathrm{M}=-.93997, \mathrm{SD}=.34892, \mathrm{p}<.01$. The other factors 
including language barrier, $\mathrm{M}=.8792, \mathrm{SD}=.3888, \mathrm{p}<.05$, and parental involvement in drugs or antisocial activities, $\mathrm{M}=-.37204, \mathrm{SD}=.15227, \mathrm{p}<$ .05 , did not reach Bonferroni criteria for significance (.01).

\section{Discussion}

The main purpose of this multistage investigation was to explore the risk factors associated with low academic achievement and to compare high, medium and low academic achievers on these factors at undergraduate level. The current scale is comprehensive as it focuses on salient factors related to low academic achievement that previously had not been combined in a single measure (Nunnally \& Bernstein, 1994). These factors included lack of motivation, dysfunctional parental practices, parental involvement in drugs or antisocial activities, relationship problems with peers and language barrier. The overall variance explained by all of these factors accounted for 57\%. The current study provided confirmatory evidence to previously identified themes in literature (Bean, Bush, McKenry, \& Wilson, 2003; Buddy, 2007; Buhs \& Ladd, 2001; Diaz, 2003; Eamon, 2005; Oliverez \& Tierney, 2005; Turner, Chandler, \& Heffer, 2009).

The present results are in line with previous studies (Baker et al., 1998; Lufi \& Cohen, 2003) indicating that low academic achievers are significantly different from high and medium academic achievers regarding low motivation characteristics. Sarwar, Bashir, Naemullah and Khan (2009) conducted a study with Pakistani secondary school students and found that the high achievers showed better study orientation and study habits than the low achievers. Literature (Jeynes, 2005; Mandara, 2006; Moss \& St.Laurent, 2001; Whitlock, 2006) has emphasized that parental support and warmth and monitoring are the key parental characteristics that enhance student's academic performance even after entering college. The present findings supported the literature (Shek, Lee, \& Chan, 1998; Stewart, 2007) indicating that in comparison to students with high academic achievement, the parents of students with low academic achievement significantly indicate higher level of dysfunctional parental practices (e.g., parental 


\section{Jibeen \& Khan-Risk Factors Academic Achievement}

strictness, lack of monitoring etc). In another study, Casanova, GarciaLinares, Torre, and Carpio (2005) found that in the group of students with low achievement, parents were classified as authoritarian, permissive and indifferent. Further, students with problems reported that their parents show lower levels of supervision, support and affection as well as higher levels of conflict than students with no achievement problems.

The incidence of dysfunctional parental practices and low academic performance can be justified by observing a significant gap in the dropout rate between students who have a strong family background and those who have a weak background. It has been suggested that parental involvement activities and family practices are more important for helping students succeed in school than are family structure including socioeconomic status or characteristics such as race, family size, or age of child (Hidalgo, Epstein \& Siu, 2002). It is important to note that parenting forms the basis of a family environment and without parental education; it may not possible for them to fulfill their roles and duties in the family and the society (Kordi \& Baharudin, 2010; Sinha \& Singh, 1998). It seems that educated parents seem to provide all possible support services including coaching, guidance and facilities to their children as they are more competent than uneducated parents. For example, Hidalgo, Epstein and Siu (2002) found that education contributes to improve the parents' capacity to intervene in their children's education, for instance, establishing supportive home environments for children and helping children out with their homework. At the other hand, when the parents have little knowledge about the specific demands of academic fields and their children's lack of potential to succeed in different fields, they are more likely to practice authoritarian parenting to fulfill their own aspirations (Rudy \& Grusec, 2006).

Research (Anna \& Nattavudh, 2009; Hasnain \& Krantz , 2010) indicates that the students from higher socio-economic and more educated backgrounds have lower rates of dropouts whereas those from poor and uneducated background higher rates of dropouts in Pakistan. The family structure affects children through the degree to which family members provide resources or compete for them. As extended family members who live with their children are generally poorer, less healthy, and less educated. Thus, children who live with extend family members (especially grand- 
parents) typically have lower academic achievement than those who do not live with extended family members (Ainsworth, 2013). A child's parents might give or lend money to poor relatives, thereby reducing the immediate resources available to the child. Moreover, siblings and extended family members share parents' attention, so children with more siblings have lower academic achievement (Chadda \& Deb, 2013). Recently, Hasnain and Krantz (2010) investigated the risk factors associated with college dropouts among young adults in Karachi, Pakistan, and found that migrant residential status, living in an extended family and lower socio-economic status were identified as risk factors for college dropouts both for males and females.

The present results indicated that the low academic achievers significantly revealed parental substance abuse or criminal activities than did high achievers (Dallaire, Ciccone, \& Wilson, 2010). One important potential explanation is that adult children of substance abusing parents may show cognitive deficits that impact their academic performance in college (Solis, Shadur, Burns, \& Hussong, 2013; Winters, 2006). These adult college students (respectively) are typically exposed to negligent or abusive parenting and financial hardships. It is important to note that academic difficulties in children of alcoholics are partly due to less parental involvement in their academic activities, lower levels of family organization and less parental involvement in their college or school educational activities (Gonzalez-DeHass, Willems, \& Holbein, 2005).

The current analyses revealed significant peer relationship problems and uncomfortable feelings in coeducational setting in the low and middle achiever students than did high achievers. The present findings are in line with literature (Thompson \& Ungerleider, 2004) indicating that students from single-sex schools score higher than students from coeducational schools. It has been noted that single-sex schools actually benefit boys the most-specifically, boys from minority groups and boys from poor families who may need more direct guidance (Guarisco, 2010). For example, Hopkins (1997) found that single sex schooling is particularly effective for low-income African, American and Hispanic boys.

Working from a social psychological perspective, advocates of single sex environment describe concerns about the negative stereotypes, low 
expectations, and relative lack of student and adult role models in coeducational schools (Singh, Vaught, \& Mitchell, 1998). In a recent study, Ogden (2011) found that single-sex environments help to reduce gender stereotypes that students encounter in coeducational settings and they are generally more settled and more relaxed (Sax, 2008; Wills, 2007). Though it is claimed that single-sex schools are superior to coeducational schools, in reducing sex differences, but in most countries, single-sex schools tend to be private, whereas coeducational schools tend to be government; therefore, this hypothesis is very hard to test in an unconfounded way (Thompson \& Ungerleider, 2004).

Literature (Carlivati, 2001; Liem \& Martin, 2011) suggests that students doing well in school have been found to have a close friend than those rejected by peers. Researchers (Buote, 2002; Martin, 2012; Martin \& Dowson, 2009; Stewart, 2007) noted that the involvement with positive peer group activities contributes to academic success, controls violent inclinations and increase the expression of pro-social behavior. In a recent study (Swenson Goguen, Hiester, \& Nordstrom, 2010) the importance of peer relationships to academic outcomes of first-year undergraduates was tested and it was found that sharing common interests and having trust in peer was positively related to GPA while the extent of conflict with a new college friend was associated negatively with GPA and persistence to the second college year.

Finally, in current sample, the students revealing low proficiency in English language reported low academic performance as compared to high academic performance. These finding are in line with previous literature (Butler \& Castellon-Wellington, 2005; Francis \& Rivera, 2007; Kong, Powers, Starr \& Williams, 2012; Parker, Louie \& O’Dwyer, 2009) suggesting that low language proficiency has been considered a barrier to learning and academic success at the post-secondary level because sufficient level of English language proficiency is needed to be able to demonstrate content knowledge on academic assessments. 


\section{Limitations}

One of the limitations of the current study is the moderate reliability of subscales as Cronach's alphas for the subscales were moderate. In the resent study, probably the small number of items in each subtest and limited (4-points' scale) width resulted in these "relative moderate coefficients". Indeed, it has been shown that Cronbach's alpha estimation of reliability increases with scale length (Voss, et al., 2000). Other limitations include the use of self-report questionnaires to assess the outcome variables, the lack of temperament and IQ measures to assess how student temperament factors and ability affect the perception of the variables reported, and the cross-sectional nature of the study. Another limitation is related to the lack of information about those students who might have learning disabilities as they need comprehensive assessment separately using appropriate questionnaires.

\section{Implications}

The current study has demonstrated the utility of risk-focused ecological model that could be effective in improving academic achievement of students. The academic achievement predictive model is particularly important for college student personnel that are looking for ways to identify students who are at risk for academic difficulties. It is important to note that the college counselors might use these data as an impetus for furthering development of behavior modification of parents and students. For example, there is need for the promotion of parenting programs emphasizing home environments of warmth and autonomy during adolescence to help students be more academically successful throughout their education. These programs would help students develop skills that an authoritative home environment imparts, such as elements of mastery and persistence, which are important for success in college. 
42 Jibeen \& Khan-Risk Factors Academic Achievement

\section{References}

Ainsworth, J. (2013). Sociology of Education: An A to Z guide. Los Angeles: Sage.

Akram, M., \& Khan, F. J. (2007). Public provision of education and government spending in Pakistan. Islamabam: Institute of Development Economics.

Ali, N., Jusoff, K., Ali, S.,Mokhtar, N., Syafena, A., \& Salamats, A. (2009).

The factors ninfluencing students' performance at University

Teknologi Mara Kedah, Malaysia. Management Science and

Engineering, 3(4), 81-90. Retrieved from

http://www.cscanada.net/index.php/mse/article/download/j.mse.1913

035X20090304.010/820

Anna, V.F., \& Nattavudh, P. (2010). The socioeconomic gap in university dropouts. The B.E. Journal of Economic Analysis \& Policy, 9(1), Retrieved from http://eprints.lse.ac.uk/26478

Aunola, K., Stattin, H., \& Nurmi, J. E. (2000). Parenting styles and adolescents' achievement strategies. Journal of Adolescence, 23, 205-222. doi:10.1006/jado.2000.0308

Awan, R, N., Noureen, G., \& Naz, A. (2011). A study of relationship between achievement motivation, self-concept and achievement in English and Mathematics at secondary level. International Education Studies, 4(3), 72-79. doi:10.5539/ies.v4n3p72

Baker, J. A., Bridger, R., \& Evans, K. (1998). Models of underachievement among gifted preadolescents: The role of personal, family, and school factors. Gifted Child Quarterly, 42(1), 5-15. doi:10.1177/001698629804200102

Barro, R., \& Lee, J. (2010). A new data set of educational attainment in the world, 1950-2010. NBER Working Paper Series (no. 15902).Retrieved from http://www.nber.org/papers/w15902

Bartlett, M. S. (1954). A note on the multiplying factors for various chisquare approximations. Journal of Royal Statistical Society, 16, 296298.

Bean, R, A., Bush, K, R., McKenry, P, C., \& Wilson, S. M. (2003). The impact of parental support, behavioral control, and psychological 
control on the academic achievement and self-esteem of African American and European American adolescents. Journal of Adolescent Research, 18(5), 523-541. doi:10.1177/0743558403255070

Buote, C.A. (2002). Relations of autonomy and relatedness to school functioning and psychological adjustment during adolescence. Dissertation Abstracts International Section A: Humanities and Social Sciences, 62(1). doi:10.14288/1.0053902

Buddy, T. (2007). Negative effects of parental drinking. Parental drinking affects children's behavior. Retrieved from http://alcoholism.about.com/cs/tipsforparents/a/aa000725a.html

Buhs, E.S., \& Ladd, G.W. (2001). Peer rejection as an antecedent of young children's school adjustment: An examination of mediating processes. Developmental Psychology, 37, 550-560. doi:10.1037/0012-1649.37.4.550

Butler, F. A., \& Castellon-Wellington, M. (2005). Students' concurrent performance on tests of English language proficiency and academic achievement. The validity of administering large-scale content assessments to English language learners: An investigation from three perspectives. CSE Rep. NO. 663. Los Angeles: University of California.

Carlivati, J. (2001). Adolescent attachment, peer relationships, and school success: Predictor, mediator, and moderator relations. Distinguished Majors Thesis. Charlottesville: University of Virginia.

Casanova, P., Garcia-Linares, C., Torre, M. J., \& Carpio, M, V. (2005). Influence of family and socio demographic variables on students with low academic achievement. Educational Psychology, 25(4), 423435. doi:10.1080/01443410500041888

Chadda, R.K., \& Deb, K.S. (2013). Indian family systems, collectivistic society and psychotherapy. Indian Journal of Psychiatry, 55(2), 299309. doi:10.4103/0019-5545.105555

Churchill, G. (1979). A paradigm for developing better measures of marketing constructs. Journal of Marketing Research, 16, 64-73. doi:10.2307/3150876 
Cohen, J. (2001). Parental nudging underscores the lesson that it's important for children to do well. Retrieved from http://www.apa.org/monitor/sep01/momshelp.aspx

Dallaire, D, H., Ciccone, A., \& Wilson, L. C. (2010). Teachers' experiences with and expectations of children with incarcerated parents. Journal of Applied Developmental Psychology, 31(4), 281-290. doi:10.1016/j.appdev.2010.04.001

Dannis, J. M.,Phiney, J.S., \& Chuateco, L.I. (2005). The role of motivation, parental support, and peer support in the academic success of ethnic minority first- generation college students. Journal of College Students, 46(3), 223-236. doi:10.1353/csd.2005.0023

Deberard, M, S., Spielmans,G, I., \& Julka, D. L. (2004). Predictors of academic achievement and retention among college freshmen: A longitudinal study. Retrieved from http://www.questia.com/googleScholar.qst?docId=5006016936

Diaz, A. L. (2003). Personal, family and academic factors affecting low achievement in secondary school. Electronic Journal of Research in Educational Psychology and Psychopedagogy, 1(1), 43-66. Retrieved from www.investigacion-

psicopedagogica.com/revista/articulos/1/english/Art_1_4.pdf

Downey, D. B., \& Yuan, A. S. (2005). Sex differences in school performance during high school: Puzzling patterns and possible explanations. The Sociological Quarterly, 46, 299-321.

doi:10.1111/j.15338525.2005.00014.x

Eamon, M. K. (2005). Social-demographic, school, neighborhood, and parenting influences on the academic achievement of Latino young adolescents. Journal of Youth and Adolescence, 34(2), 163-174. doi:10.1007/s10964-005-3214-x

Fass, M. E., \& Tubman, J.G. (2002).The influence of parental and peer attachment on college students' academic achievement. Psychology in the Schools, 39(5), 561-573. doi:10.1002/pits.10050

Fillmore, K. M. (1987). Prevalence, incidence, and chronicity of drinking patterns and problems among men as a function of age: a longitudinal and cohort analysis. British Journal of Addiction, 82, 77-83.

doi:10.1111/j.1360-0443.1987.tb01440.x 
Francis, D. J., \& Rivera, M. O. (2007). Principles underlying English language proficiency tests and academic accountability for ELLs. In J. Abedi (Ed.), English language proficiency assessment in the nation: Current status and future practice (pp. 13-31). California: University of California.

Gonzalez-DeHass, A.R., Willems, P.P., \& Holbein, M.F.D. (2005). Examining the relationship between parental involvement and student motivation. Educational Psychology Review, 17, 199-123. Guarisco, C. (2010). Single-sex schools and gender roles: Barrier or breakthrough? Retrieved from www.luc.edu/law/academics/special/center/.../Chrissy_Guarisco.pdf Hasnain, S., \& Krantz, G. (2010). Assessing reasons for school/college dropout among young adults and implications for awareness about STDs and HIV/AIDS: Findings from a population-based study in Karachi, Pakistan. International Journal of Behavior Medicine, 18, 122-130. doi:10.1007/s12529-010-9074-0

Hickman, G. P., Bartholomae, S., \& McKenry, P. C. (2000). Influence of parenting styles on the adjustment and academic achievement of traditional college freshmen. Journal of College Student Development, 41, 41-54.

Hidalgo, N. M., Epstein, J. K., \& Siu, S. (2002). Research on families, schools, and communities. A multicultural perspective. In J.A. Banks \& C.A. Banks (Eds.), Handbook of Research on Multicultural Education. New York: Macmillan.

Hopkins, R. (1997). Educating Black males: Critical lessons in schooling, community, and power. Albany: State University of New York Press.

Jeynes, W. H. (2005). A meta-analysis of the relation of parental involvement to urban elementary school student academic achievement. Urban Education, 40, 237-269. doi:10.1177/0042085905274540

Jöreskog, K. G., \& Sorbom, D. (1993). LISREL 8: Structural equation modeling with the SIMPLIS command language. Chicago: Scientific Software International.

Kaiser, H. F. (1974). An index of factorial simplicity. Psychometrika, 39, 31-36. doi:10.1007/BF02291575 
Kirby, D., \& Sharpe, D. (2001). Stud attrition from Newfoundland and Labrador's public college. Alberta Journal of Educational Research, 47, 353-368. Retrieved from

http://ajer.journalhosting.ucalgary.ca/index.php/ajer/article/view/288

Kong, J., Powers, S., Starr, L., \& Williams, N. (2012). Connecting English language learning and academic performance: A prediction study. Vancouver: Pearson.

Kordi, A., \& Baharudin,R. (2010). Parenting attitude and style and its effect on children's school achievements. International Journal of Psychological Studies 2(2), 217-222. doi:10.5539/ijps.v2n2p217

Liem, G, A., Martin, A, J. (2011). Peer relationships and adolescents' academic and non-academic outcomes: Same-sex and opposite-sex peer effects and the mediating role of school engagement. British Journal of Educational Psychology, 81(2), 183-206. doi:10.1111/j.2044-8279.2010.02013.x

Lufi, D., \& Cohen, A. (2003). Persistence in higher education and its relationship to other personality variables. College Student Journal, $37(1), 50-59$.

Lynn, M. R. (1986). Determination and quantification of content validity. Nursing Research, 35(6), 382-385. Retrieved from http://journals.lww.com/nursingresearchonline/Citation/1986/11000/ Determination_and_Quantification_Of_Content.17.aspx

Ma, X., \& Xu, J. (2004). Determining the causal ordering between attitude toward Mathematics and achievement in Mathematics. American Journal of Education, 10(1), 256-280. doi:10.1086/383074

Mandara, J. (2006). The impact of family functioning on African American males' academic achievement: A review and clarification of the empirical literature. Teachers College Record, 108(2), 206-223. doi:10.1111/j.1467-9620.2006.00648.x

Martin, A. J. (2009). Interpersonal relationships, motivation, engagement, and achievement: Yields for theory, current issues, and educational practice. Review of Educational Research, 79, 327-365. doi:10.3102/0034654308325583

Martin, A. J. (2012). Interpersonal Relationships and Students' Academic and Non-Academic Development. What Outcomes Peers, Parents, 
and Teachers Do and Do Not Impact. In D. Zandvliet, P. Brok \& T. den Mainhard (Eds.), Interpersonal Relationships in Education. From Theory to Practice. Dordrecht: Springer.

Martin, A. J., \& Dowson, M. (2009). Interpersonal Relationships, Motivation, Engagement, and Achievement: Yields for Theory, Current Issues, and Educational Practice. Review of Educational Research, 79(1), 327-365. doi:10.3102/0034654308325583

McCoach, D. B., \& Siegle, D. (2001). A comparison of high achievers' and low achievers' attitudes, perceptions, and motivation. Academic Exchange Quarterly, 5(2), 71-76.

McCoach, D.B., \& Siegle, D. (2003a). Factors that differentiate underachieving gifted students from high-achieving gifted students. Gifted Child Quarterly, 47, 144-154. doi:10.1177/001698620304700205

McCoach, D. B., \& Siegle, D. (2003b). The structure and function of academic self-concept in gifted and general education samples. Roeper Review, 25, 61-65. doi:10.1080/02783190309554200

Moss, E., \& St.-Laurent, D. (2001). Attachment at school age and academic performance. Developmental Psychology, 37, 863-874. doi:10.1037//0012-1649.37.6.863

Nunnally, J., \& Bernstein, I. H. (1994). Psychometric theory. New York: McGraw-Hill.

Ogden, C, E. (2011). A comparison of student performance in single sex education and coeducational setting in urban middle schools. Retrieved from http://digitalcommons.georgiasouthern.edu/etd Oliverez, P. M. \&, Tierney, W. G. (2005). Show us the money: Lowincome students, families, and financial aid. Los Angeles, CA: University of Southern California.

Parker, C. E., Louie, J., \& O’Dwyer, L. (2009). New measures of English language proficiency and their relationship to performance on largescale content assessments (Issues \& Answers). Retrieved from http://ies.ed.gov/ncee/edlabs

Pearson, J., \& Child, J. (2007). Across cultural comparison of parental and peer attachment styles among adult children from the United States, Puerto Rico, and India. WCA Conference, Brisbane. 
Peelo, M., \& Wareham, T. (2002). Failing students in higher education. Philadelphia: Sreh \& Open University Press.

Rudy, D., \& Grusec, J. E. (2006). Authoritarian parenting in individualist and collectivist groups: Associations with maternal emotion and cognition and children's self-esteem. Journal of Family Psychology, 20,68-78. doi:10.1037/0893-3200.20.1.68

Rumberger, R, W. \& Larson, K. A. (1998). Toward explaining differences in educational achievement among Mexican American languageminority students. Sociology of Education, 71, 69-93.

doi:10.2307/2673222

Sarwar, M., Bashir, M., Naemullah, M., \& Khan, M., \& Khan, M. S. (2009). Study-orientation of high and low academic achievers at secondary level in Pakistan. Educational Research and Review, 4(4), 204-207.

Sax, L. J. (2008). The gender gap in college: Maximizing the developmental potential of women and men. San Francisco: Jossey-Bass.

Shek, D. T. L, Lee, T. Y., \& Chan, L. K. (1998). Perceptions of parenting styles and parent-adolescent conflict in adolescents with low academic achievement in Hong Kong. Social Behaviour and Personality, 26, 89-98. doi:10.2224/sbp.1998.26.1.89

Singh, K., Vaught, C., \& Mitchell, E. W. (1998). Single-sex classes and academic achievement in two inner-city schools. Journal of Negro Education, 67, 157-167. doi:10.2307/2668225

Sinha, S. B. P., \& Singh, A. E. (1998). Effect of parents' affection and competence on the home adjustment of school students. Indian Psychological Review, 50(2), 106-112.

Solis, J, M., Shadur, J, M., Burns, A, R., \& Hussong, A, M. (2012).

Understanding the diverse needs of children whose parents abuse substances. Current Drug Abuse Review, 5(2), 135-147.

Stewart, E. B. (2007). Individual and school structural effects on African American high school students' academic achievement. High School Journal, 91, 16-34. doi:10.1353/hsj.2008.0002

Swenson Goguen, L. M., Hiester, M. A., \& Nordstrom, A. H. (2010). Associations among peer relationships, Academic achievement and 
Persistence in College. Journal of College Student Retention: Research, Theory \& Practice, 12(3), 319-337. doi:10.2190/CS.12.3.d Tella, A. (2007). The impact of motivation on student's academic achievement and learning outcomes in Mathematics among secondary school students in Nigeria. Eurasia Journal of Mathematics, Science \& Technology Education, 3(2), 149-156. Retrieved from http://www.ejmste.com/v3n2/ejmste_v3n2_tella.pdf Thompson, T., \& Ungerleider, C. (2004). Single sex schooling final report. Retrieved from http://www.cmec.ca/publications/lists/publications/attachments/61/si nglegender.en.pdf

Triandis, H. C. (1989). The self and social behavior in differing cultural contexts. Psychological Review, 96, 506-52. doi:10.1037/0033295X.96.3.506

Turner, E. A., Chandler, M., \& Heffer, R.W. (2009). The influence of parenting styles, achievement motivation, and self-efficacy on academic performance in college students. Journal of College Student Development, 50 (3), 337-346. doi:10.1353/csd.0.0073

UNESCO. (2005). Education for All. The Quality Imperative. Global Monitoring Report. Retrieved from http://unesdoc.unesco.org/images/0013/001373/137333e.pdf

Voss, K. E., Stem, D. E., Jr. \& Fotopoulos, S. (2000). A comment on the relationship between coefficient alpha and scale characteristics. Marketing Letters, 11(2), 177-191. doi:10.1023/A:1008146924781

Whitlock, J. L. (2006). Youth perceptions of life at school: Contextual correlates of school connectedness in adolescence. Applied Developmental Science, 10, 13-29. doi:10.1207/s1532480xads1001_2

Wills, R. (2007). A new and different space in the primary school: Singlegendered classes in coeducational schools. Educational Studies, 33(2), 129-143. doi:10.1080/03055690601068303

Winters, A. (2006). Influential factors of parental substance and alcohol abuse on children's academic achievement. PSU McNair Scholars Online Journal, 2(1), 1-19. doi:10.15760/mcnair.2006.378 
50 Jibeen \& Khan-Risk Factors Academic Achievement

Zeller, R. A., \& Carmines, E.G. (1980). Measurement in the social sciences: The link between theory and data. NY: Cambridge University Pres.

Tahira Jibeen is Assistant Professor at the COMSATS Institute of Information Technology, Lahore, Pakistan.

Masha Asad Khan is Assistant Professor at the Forman Christian College:A Charted University, Lahore, Pakistan.

Contact Address: Tahira Jibeen, Humanities Department, COMSATS Institute of Information and Technology, Lahore 5400, Pakistan. Email: tahirajibeen@ciitlahore.edu.pk 